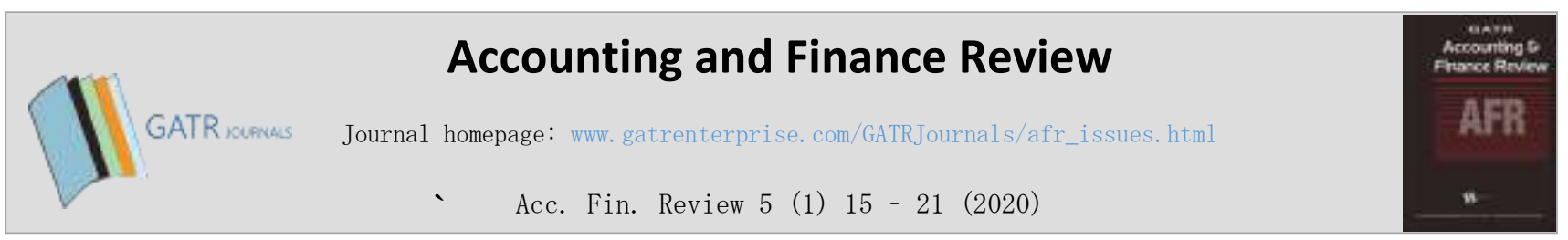

\title{
Corporate Governance and Financial Ratios Effect on Audit Report Lag
}

\author{
Friska Firnanti $^{*}$, Arwina Karmudiandri ${ }^{2}$ \\ ${ }^{1,2}$ Trisakti School of Management, 11440, Jakarta, Indonesia
}

\begin{abstract}
Objective - the timeliness of financial statement submission becomes important in decision making. With the growing importance of timely financial statements for the relevance of decision making, an understanding of the determinants of audit report lag becomes necessary. This research intends to obtain empirical evidence that corporate governance through board and audit committee characteristics, specifically size, meetings, independence and expertise has an influence on audit report lag. Financial ratios through firm size, profitability and leverage are tested to determine their influence on audit report lag.

Methodology/Technique - Hypothesis tests with multiple regression are used with non-financial firms listed on the Indonesian Stock Exchange between 2015 to 2017. This research uses purposive sampling with the result of 204 companies sampled and 612 data sets used in the model.

Findings - The result of this research show that board size, board meetings, board independence, audit committee size, firm size and profitability all have an influence on audit report lag. Meanwhile, audit committee independence, audit committee expertise, and leverage have no influence on audit report lag.
\end{abstract}

Type of Paper: Empirical

Keywords: Board Characteristics; Audit Committee; Financial Ratio; Audit Report Lag.

Reference to this paper should be made as follows: Firnanti, F; Karmudiandri, A; (2020). Corporate Governance and Financial Ratios Effect on Audit Report Lag, Acc. Fin. Review, 5 (1): 15 - 21. https://doi.org/10.35609/afr.2020.5.1(2)

JEL Classification: M40, M41, M49

\section{Introduction}

Decision making related to the combination of capital structure is a very sensitive issue, because a company should perform well to maximize its value and shareholder's wealth. Therefore, company's factors as an internal factor and market conditions as an external factor should be considered to decide the optimal proportion of capital structure, whether to using debt or equity. Corporate governance is the foundation for companies to develop institutional performance. Financial reporting is an ideal tool to express the efficiency of a company's corporate governance (Warrad, 2018).

\footnotetext{
* Paper info: Revised: December 13, 2019

Accepted: March 31, 2020

* Corresponding author: Friska Firnanti

E-mail: friska@stietrisakti.ac.id

Affiliation: Accounting, Trisakti School of Management, Indonesia
} 
The effectiveness of the company's financial statements can be seen from the audit report lag. Timeliness in completing financial statements to the public is beneficial so that information remains relevant and has the ability to influence decisions. This will reduce investor uncertainty in decision making (Abdillah \& Habiburrochman, 2019). The total days between the company's financial year end and the date of the audit report is referred to ass audit report lag (Ahmed \& Che-Ahmad, 2016). In Indonesia, the timeliness of submitting public companies' financial reports is regulated by Bapepam Regulation Number XK2, which states that annual financial reports must be submitted and publicly announced by the end of the third month after the annual financial reports date. In accordance with applicable regulations, companies will be subject to sanctions if they do not follow these rules, such as receiving a written warning from the Exchange, the imposition of fines, and suspension sanctions. However, despite these regulations, many companies still submit their financial reports must later than the specified date and this can be detrimental to investors and shareholders.

Corporate governance is expected to maximize management performance and minimize delays in the delivery of financial statements. One part of corporate governance is the existence of a company board and audit committee. The characteristics of the board and audit committee correspond with the quality of internal control (Hoitash et. al., 2009). Corporate governance through board characteristics, such as size, meetings, independence and audit committee characteristics, such as size, independence, and expertise are seen to minimize audit report lag. In addition, this research seeks to obtain empirical evidence on the influence of financial ratios, through firm size, profitability and leverage to audit report lag. With the importance of audit lag for investor decision making, research on the determinants of audit report lag have been carried out in studies such as those conducted by Abernathy et. al. (2017), Sharma et. al. (2017) and Sultana et. al. (2015). The problem can be stated as: Does board characteristics, as of size, meetings, independence and audit committee characteristics, as of size, independence, and expertise, firm size, profitability and leverage affect audit report lag?

\section{Literature Review}

\subsection{Audit Report Lag}

The delay in submitting audited financial reports cannot be separated from the company's management. In Agency Theory, coined by Jensen and Meckling (1976), the agency relationship is defined as the relationship of principal with the manager (agent) to perform services in the company according to the principal goals, where the agent is given authority by the principal to make decisions. The principal as an outside party does not have enough information about the performance of the agent and does not have certainty about the extent of the agent's efforts in providing input to gain results from the company's operations.

Audited financial reports become a media that is used by management in communicating with their environment. Signaling Theory is the root of the emergence of asymmetric information, which can arise when one party sends a signal that will show some information to the other party. Ross (1977) states that asymmetric information can be used by companies to submit financial reports as a good signal to the market. Information submitted by managers to the market reduces asymmetric information and will be considered a good signal by the market. Widati and Septy (2008) state that the timeliness of presenting financial statements is a signal from companies that shows the existence of useful information in the need for decision making from investors. The longer the delay in publishing audited financial reports, the more likely that a little or more information can be leaked to certain party or even lead to insider trading and rumors on the stock market. 


\subsection{Board Size}

Board size is one component that oversees whether the company has implemented good corporate governance. To avoid delays in publishing financial report is the role of company's board and it is also very important for the company (Joened \& Gusti, 2016). Board size is one component of corporate governance that influences audit report lag, with the supervision function to management policies. Jao and Chrismayani (2018) state that the greater the size of the board, the supervision conducted by the board will be much better, so that it can improve company performance and will also improve the quality of the company's financial statements so that it will reduce audit report lag.

H1: Board size has an effect on audit report lag.

\subsection{Board Meetings}

The meeting of the board of directors is for the purpose of conducting internal supervision so that the productivity and professionalism of the company improves (Kuslihaniati \& Hermanto, 2016). With more frequent meetings held, the board can work in accordance with the functions and correct in doing his work, which will have influence on the timeliness of corporate financial reports.

H2: Board meetings have an effect on audit report lag.

\subsection{Board Independence}

According to Juniarti and Agnes (2009), board independence is a board member who comes from outside of the company and has nothing to do with management, other boards of directors or with shareholders that can influence their independence. Jao and Chrismayani (2018) state that board independence has a positive effect on audit report lag. The more board independence a company has, the longer it will take to examine and publish the company's financial statements.

H3: Board independence has an effect on audit report lag.

\subsection{Audit Committee Size}

An audit committee is responsible for overseeing financial statements, observing a company's systems of internal control and overseeing external audits. An audit committee is expected to help resolve conflicts with management which can cause a decrease in audit quality (Karamanou \& Vafeas, 2005). The greater the audit committee size, the greater the quality of supervision. There is an increased chance that problems in process of reporting can be found and resolved if there is a larger audit committee. Ahmad and Che-Ahmad (2016) state that a greater number of audit committee members can reduce audit report lag.

H4: Audit committee size has an effect on audit report lag.

\subsection{Audit Committee Independence}

Independence of the audit committee can ensure quality financial reports. Independent audit committee is a member of the audit committee who do not carry out executive duties (Apadore \& Noor, 2013). Usually, an independent audit committee will demand higher results. With this, the audit will take longer and will have an impact on the timeliness of the company's financial reporting.

H5: Audit committee independence has an effect on audit report lag.

\subsection{Audit Committee Expertise}

An audit committee consist of experts who are experienced in operating and also understanding the tasks entrusted to the audit committee itself can make it easier to identify errors and can also communicate with 
external auditor (Apadore \& Noor, 2013). Audit committee expertise has an important part in dealing with external auditors, because the audit committee can mediate management and auditors. The greater the audit committee expertise, the greater probability that mediation will be carried out and extend audit report lag.

H6: Audit committee expertise has an effect on audit report lag.

\subsection{Firm Size}

Large companies can complete their audits with shorter lag than smaller companies. Larger companies may have more complex internal controls, which in turn will reduce the tendency for errors in financial statements to occur and allow auditors to rely on controls and to do more interim work (Juanita \& Satwiko, 2012). Large companies have more funds for higher audit fees to conduct audits immediately after the financial year end and management may have incentives to minimize audit delay and report delays because they are more closely monitored by investors (Modugu et. al., 2012).

H7: Firm size has an effect on audit report lag.

\subsection{Profitability}

According to Juanita and Satwiko (2012), profitability can be used as a measure of management performance, where high profitability reflects good management performance. Good performance is a good news for better reputation in the public eye, so management will immediately report and publish the good news. The results of research by Lianto and Kusuma (2010) show that the higher profitability, the shorter audit report lag will be. Higher profitability company tend to need faster auditing of financial statements because of the demand to deliver the good news as early as possible to the public.

H8: Profitability has an effect on audit report lag.

\subsection{Leverage}

Leverage will increase the tendency of loss and can increase the auditor's caution of the financial statements to be audited. Bigger proportion of liability will increase its financial risk. Therefore companies that have problems in financing its operation tend to be able to do mistake in financial management or fraud. A high proportion of debt to total assets will affect liquidity associated with going concern, which ultimately requires more careful auditing. Lianto and Kusuma (2010) state that high amount of debt owned by the company will cause a relatively longer audit process. Auditors need to increase caution and more careful audit in relation to the company's survival problems. Thus,

H9: Leverage has an effect on audit report lag.

\section{Research Methodology}

This research uses secondary data with a population of non-financial public firms listed on the Indonesian Stock Exchange. The sampling method used in this research is purposive sampling. The period used in this research is from 2015 to 2017. The companies included in the research sample are non-financial public firms on the Indonesian Stock Exchange between 2015-2017 that have published financial reports ending on December 31 in Rupiah and have reported the number of board meetings held between 2015-2017. Data is obtained from the annual audited financial statements. The total sample is 204 companies with 612 data sets.

\subsection{Operational Definition}

The length of audit report lag was obtained from the length of days needed to obtain an audit report on the company's annual financial reports, from the closing date of the company, until the date stated on the audit report (Ahmed \& Che-Ahmad, 2016). Board size was obtained from the members of the board of directors 
(Ilaboya \& Christian, 2014). The number of board meetings held was determined by the number of board meetings held in 1 year (Kuslihaniati \& Hermanto, 2016). Board independence was obtained using the proportion of independent directors (Apadore \& Noor, 2013). Audit committee size was obtained by using the number of audit committee members. The audit committee independence variable was obtained by using the percentage of non-executive directors with the total number of members of the audit committee. Audit committee expertise was obtained by using the number of audit committee members with background experience in financial reporting. Firm size was obtained by using the logarithm of total assets, profitability was obtained by using ROA. Leverage was obtained by the ratio of total debt to total assets (Almilia \& Setiady, 2012).

\section{Results}

The result of the research hypothesis tests are shown in Table 1 below.

Table 1. Hypothesis Results

\begin{tabular}{|c|c|c|}
\hline Variable & B & Sig. \\
\hline (Constant) & 116.229 & 0.000 \\
\hline Board Size & -2.077 & 0.000 \\
\hline Board Meetings & -0.315 & 0.008 \\
\hline Board Independence & 17.835 & 0.005 \\
\hline Audit Committee Size & -2.259 & 0.043 \\
\hline Audit Committee Independence & 3.764 & 0.393 \\
\hline Audit Committee Expertise & 1.331 & 0.113 \\
\hline Firm Size & -2.573 & 0.008 \\
\hline Profitability & -28.399 & 0.000 \\
\hline Leverage & 0.228 & 0.506 \\
\hline
\end{tabular}

The result of this research show that board size, board meetings, board independence, audit committee size, firm size and profitability all have an influence on audit report lag. Meanwhile, audit committee independence, audit committee expertise, and leverage have no significant effect on audit report lag. The responsibility of the board of directors is to monitor the quality of information contained in the financial reports that are published to the public (Ilaboya \& Christian, 2014). With the presence of the board and audit committee, it is expected that audit report lag can be minimized. The more meetings of the board of commissioners of a company may shorten audit report lag. On the other hand, the more independent board members, the longer the audit report lag may be. Firm size and profitability have a negative effect on audit report lag. Large companies have great pressure to process information, so that management will make the presentation of financial statements more timely. Profitability is also a good signal for stakeholders, so the company will try to convey this positive signal as soon as possible (Modogu et. al., 2012).

\section{Conclusion}

The timeliness of reporting financial statements is very important for corporate stakeholders. If the company has a good corporate governance structure and process, this will become an important part in improving the timeliness of financial statements (Daout et. al., 2015). The supervisory mechanism by the company board and audit committee influences how long the process of preparing and publishing the financial report takes. However, supervision needs to be carried out effectively and efficiently. If the mechanism is not running efficiently, it cannot affect audit report lag and may lose its supportive function as 
a tool in improving the company's reporting performance. The company's financial condition also plays a role in the timeliness of company reporting. Thus, further research may add other variables such as contingency reporting. Companies are expected to minimize audit report lag to maximize the benefits of financial statements to stakeholders.

\section{References}

Abernathy, J. L., Barnes, M., Stefaniak, C., \& Weisbarth, A. (2017). An international perspective on audit report lag: A synthesis of the literature and opportunities for future research. International Journal of Auditing, 21(1), 100127.https://doi.org/10.1111/ijau.12083

Abdillah, M. R., Mardijuwono, A. W., \& Habiburrochman, H. (2019). The effect of company characteristics and auditor characteristics to audit report lag. Asian Journal of Accounting Research. https://doi.org/10.1108/AJAR-05-2019-0042 Ahmed, M. Ishaq dan Ayoib Che-Ahmad. (2016). Effects of Corporate Governance Characteristics on Audit Report Lags. International Journal of Economic and Financial Issues, 6(S7), 159-164. https://pdfs.semanticscholar.org/66d0/cc5f96ee69f460b902b5986cc06907334e11.pdf

Al Daoud, K. A., Ismail, K. N. I. K., \& Lode, N. A. (2015). The impact of internal corporate governance on the timeliness of financial reports of Jordanian firms: Evidence using audit and management report lags. Mediterranean Journal of Social Sciences, 6(1), 430.DOI: 10.5901/mjss.2015.v6n1p430

Almilia, Luciana Spica and Lucas Seiady. (2006). Factors That Affect the Completion of the Presentation of Financial Statements in Companies Listed on the JSE. Jakarta: Seminar Nasional Good Corporate Government (November 2006). https://spicaalmilia.files.wordpress.com/2007/04/penelitian-penyelesaian-lk.pdf

Apadore, Kogilavani and Marjan Mohd Noor. (2013). Determinants of Audit Report Lag and Corporate Governance in Malaysia. International Journal Business and Management, 8(15). https://doi.org/10.5539/ijbm.v8n15p151

Hoitash, U., Hoitash, R., \& Bedard, J. C. (2009). Corporate governance and internal control over financial reporting: A comparison of regulatory regimes. The accounting review, 84(3), 839-867. https://doi.org/10.2308/accr.2009.84.3.839 Ilaboya, O. J., \& Christian, I. (2014). Corporate governance and audit report lag in Nigeria. International Journal of $\begin{array}{llll}\text { Humanities } \quad \text { and } & \text { Social } & \text { Science, } & \text { 172-180. }\end{array}$ http://www.ijhssnet.com/journals/Vol_4_No_13_November_2014/20.pdf

Jao, R., \& Crismayani, F. P. (2018, December). The Effect of Corporate Governance Mechanism on Audit Delay. In the National Seminar on Research Results \& Community Service (SNP2M). http://jurnal.poliupg.ac.id/index.php/snp2m/article/viewFile/862/756

Jensen, Michael C. and William H. Meckling. (1976). Theory of the Firm: Managerial Behavior, Agency Costs and Ownership Structure. Journal of Financial Economics, 3(4), 305-360. https://doi.org/10.1016/0304-405X(76)90026-X

Joened, Jovi Ardyadi and I Gusti Ayu Eka Damatanthi. (2016). Influence of the Characteristics of the Board of Commissioners, Auditor's Opinion, Profitability, and Auditor's Reputation on the Timeliness of Financial Reporting. EJurnal Akuntansi Universitas Udayana, 14(1), 423-450. https://ojs.unud.ac.id/index.php/Akuntansi/article/view/14565 Juniarti, J., \& Sentosa, A. A. (2010). Effects of Good Corporate Governance, Voluntary Disclosure on Costs of Debt. Journal of Accounting and Finance, 11 (2), pp-88. https://doi.org/10.34208/jba.v14i1.103

Juniarti and Agnes A. Sentoso. (2009). The Effect of Good Corporate Governance, Voluntary Disclosure Against Debt Costs (Cost of Debt). Jurnal Akuntansi dan Keuangan, 11(2). https://doi.org/10.9744/jak.11.2.pp.\%2088-100

Karamanou, I., \& Vafeas, N. (2005). The association between corporate boards, audit committees, and management earnings forecasts: An empirical analysis. Journal of Accounting research, 43(3), 453-486. https://doi.org/10.1111/j.1475-679X.2005.00177.x

Kuslihaniati, Desi Fia and Suwardi Bambang Hermanto. (2016). The Influence of Corporate Governance Practices and Company Characteristics on Audit Lag Report. Journal of Science and Accounting Research, 5 (2).

Lianto, N., \& Kusuma, B. H. (2010). Factors affecting audit report lag. Journal of Business and Accounting, 12 (2), 98 107. https://doi.org/10.34208/jba.v12i2.188

Modugu, P. K., Eragbhe, E., \& Ikhatua, O. J. (2012). Determinants of audit delay in Nigerian companies: Empirical evidence. Research Journal of Finance and Accounting, 3(6), 46-55.https://nairametrics.com/wpcontent/uploads/2013/09/determinant-of-audit1.pdf

Ross, S. A. (1977). The determination of financial structure: the incentive-signalling approach. The bell journal of economics, 23-40. https://doi.org/10.2307/3003485 
Sharma, D. S., Tanyi, P. N., \& Litt, B. A. (2017). Costs of mandatory periodic audit partner rotation: Evidence from audit fees and audit timeliness. Auditing: A Journal of Practice \& Theory, 36(1), 129-149. https://doi.org/10.2308/ajpt51515

Sultana, N., Singh, H., \& Van der Zahn, J. L. M. (2015). Audit committee characteristics and audit report lag. International Journal of Auditing, 19(2), 72-87. https://doi.org/10.1111/ijau.12033

Warrad, L. H. (2018). The Extent to Which the Corporate Governance Characteristics Has Affected the Audit Report Lag in Jordanian Banks. International Journal of Business and Management, 13(12), 81-92. https://doi.org/10.5539/ijbm.v13n12p81

Widati, Listyorini Wahyu and Fina Septy. (2008). Factors Affecting the Timeframe of Presentation of Financial Statements to the Public (Empirical Study of LQ 45 Companies Listed on the Indonesia Stock Exchange). Fokus Ekonomi, 7 (3), 173-187. https://media.neliti.com/media/publications/24394-ID-faktor-faktor-yang-mempengaruhirentang-waktu-penyajian-laporan-keuangan-ke-publ.pdf 